\title{
Energy Efficiency of Eco-Friendly Home: Users' Perception
}

\author{
Maranatha Wijayaningtyas ${ }^{1, *}$, Sutanto Hidayat $^{1}$, Togi Halomoan Nainggolan $^{1}$, \\ Fourry Handoko ${ }^{2}$, Kukuh Lukiyanto ${ }^{3}$ and Azizah Ismail $^{4}$ \\ ${ }^{1}$ Civil Engineering Department, National Institute of Technology, \\ Jl. Sigura-Gura No.2, Malang, East Java, 65152 Indonesia \\ ${ }^{2}$ Industrial Engineering Department, National Institute of Technology, \\ J1. Sigura-Gura No.2, Malang, East Java, 65152 Indonesia \\ ${ }^{3}$ Entrepreneurship Program, Bina Nusantara University, Malang Campus, \\ Araya Mansion No. 8-22, Malang, East Java, 65145 Indonesia \\ ${ }^{4}$ Real Estate Department, Universiti Teknologi Malaysia, Sultan Ibrahim Chancellery Building, \\ Jl. Iman, Johor Bahru, 81310 Malaysia
}

\begin{abstract}
As the population in Indonesia grow, the use of energy in ecofriendly residences increases. Concerning this issue, the Green Building Council Indonesia provides standard criteria for greenhouses. Nevertheless, eco-friendly homes' users are still not familiar with the application of these criteria. Therefore, this research aims to investigate the users' perception of eco-friendly homes' energy efficiency. The study was conducted in Surabaya and Malang, using a cross-sectional survey method by distributing questionnaires; 200 respondents participated in the study. After the descriptive analysis, it was revealed that most of the respondents had the same perception regarding the importance of energy efficiency in their homes. According to the results, the criteria of water conservation, under the sub-criteria of using fittings for water-saving, shows the highest mean value; so, it can be concluded that the respondents prioritize the household water use efficiency more than other types of energy.
\end{abstract}

Keywords: Eco-friendly residence, greenship, household perception, water conservation, water efficiency.

\section{Introduction}

Indonesia is the fourth most populous country in the world and thus includes it as one of the suitable property locations. On top of that, it is the country with the largest economic growth rate in Southeast Asia [1]. Today, more than $50 \%$ of $240 \times 10^{6}$ Indonesians reside in urban areas. In 2025, it is estimated that $68 \%$ of the population will live in this area. Thus, housing is essential to meet the need of the growing population [2]. However, residential development in urban areas entails the concept of environmental degradation and brings fundamental changes in respect for the environment [3]. Due to its limited carrying capacity, an eco-friendly home needs to heed the needs of people and provides

\footnotetext{
*Corresponding author: maranatha@ lecturer.itn.ac.id
} 
environmental, social, and economic benefits, as well as protects the earth and mankind [4]. An eco-friendly home is a part of the sustainable development and green buildings which focuses on preventing the house resources from polluting the environment and emphasizes on energy-saving features $[5,6]$.

Based on data obtained from the Ministry of Energy and Mineral Resources of the Republic of Indonesia [7], the housing sector, especially the use of electricity, contributes more than $30 \%$ of the national energy consumption. Electricity is mostly used in urban area residences. Inevitably, this will trigger excessive use of energy, even though the effort to control the use of energy depends on the individual. Thereby, the community should possess the understanding, behavior, and motivation to use energy efficiently in pursuance of a sustainable environment [8]. Community understanding is inseparable from their social activities. Social interaction of each individual within the community generally occurs in their neighborhood. Through interaction, knowledge can be directly transferred and understood. However, each family's perception of energy efficiency will certainly be different.

The living environment might influence each individual's understanding of energy saving. Generally, energy use can be divided into contextual and psychological (behavior) categories [9]. The contextual category involves local climate, energy marketing, and attributes in buildings, including the physical and system of energy use [10]. The second category focuses on the consequences of building attributes and user characteristics [11]. Related to this matter, user satisfaction in eco-friendly homes is influenced by energy efficiency.

Green Building Council Indonesia (GBCI) is an institution that focuses on the application of the green building concept as a solution for sustainable development issues. The agency has created a system of criteria called the 'Greenship' as a standard to determine a residence's environmental friendliness. The criteria system is still new to the people of Indonesia, so it is necessary to investigate their perceptions of the criteria for environmentally friendly homes concerning energy efficiency.

\section{Energy efficiency and user behaviour}

'Energy efficiency' is a generic term. In other words, it denotes the efficient consumption of energy. It refers to low energy consumption and simultaneously produces the same or better total consumption value [12]. Some views state that energy efficiency means "energy conservation" as it refers to the same meaning. Energy conservation refers to low energy consumption along with low energy production [11]. The use of the term "energy consumption" reflects the total energy consumed. There is a close relationship between the terms; thus, their focus is interrelated in "energy consumption towards efficient use." There are eight [9] main concepts in constructing an energy-efficient building: wind break; plants and water; indoor/outdoor rooms; earth sheltering; solar walls and windows; material thermal-envelope; sun shading; and natural ventilation.

Reducing energy consumption in buildings relies on users' awareness. Several studies have explored how users' behavior may affect energy consumption in buildings. For instance, Fabi, Spigliantini and Corgnati [13] and Soares et al. [14] evaluated how different behavior patterns affect the quality of indoor climate and energy consumption. In the first study, occupants' behavior (opening and closing the house's windows) has something to do with the building control systems; in the second study, a probabilistic approach was proposed and applied to realistically simulate occupants' behavior. 


\section{Green building rate systems}

A green residential is a wise choice of home in terms of land use, efficient and effective use of energy and water, considering the material conservation of natural resources, as well as health and safetyof the occupants. The treatment and safety of green residential are also essential since the sustainability of eco-friendly home must be accompanied by the ecofriendly behavior of its occupants. Understanding the concept of green residential should be prioritized to avoid a misconceptionstating that environmentally friendly homes require high maintenance costs or that they just have a lot of green lands [15].

An establishment can be characterized as a green building if it passes the evaluation process and acquires the green building certification. A rating system is used in the evaluation of the benchmark assessment. At present, the Green Building Council of Indonesia has developed a rating tool called the 'Greenship'. This system is expected to help the green residential development elements (consumers, industry, and government) to reduce the negative impacts on the environment. By this virtue, the vision and goals of housing and settlement development in Indonesia are stipulated in the Law of Housing and Settlement Area Act No. 1, year 2011. The law states that the advancement and development of housing and habitation should be pursued as a single entity to implement the spatial function with the physical, life and social economics of culture whichcan guarantee the environment conservation and restore the quality of Indonesian people life.

In drafting the Greenship, GBCI attempted to address the local context, such as reusing water after ablution (technically, the water is still very clean). They also consider the tropical climate regarding health and comfort of rooms in the building, as well as the effect of the climate on the energy required for heating, cooling and air-conditioning (HVAC). In manufacturing, the Greenship as an assessment tool requires a reference and support from the government. Therefore, it uses the assessment criteria based on the local standards, videlicet Act, Presidential Decree, Presidential Instruction, Minister Regulation, Local Government (Province) Decree, and the Indonesian National Standard. The following regulations are the references in making the Greenship:

i. Minister Regulation of Public Works No. 30/PRT/M/2006 on Technical Guidelines and Accessibility Facilities in Buildings and Environment.

ii. Minister Regulation of Public Works No. 5/PRT/M/2008 regarding ruang terbuka hijau (green open space).

iii. Law of the Republic of Indonesia No. 28 of 2002 on Buildings.

iv. Law No. 26 of 2007 on Spatial Planning.

v. Law No. 32 of 2009 on the Protection and Environmental Management.

vi. DNA (Designated National Authority) Decree in the B-277/Dep.III /LH/01/2009

vii. Decree No. 112 of 2003 on the Gross Domestic Water Quality Standard.

viii. Minister Regulation of Public Works No. 2 /PRT/M/2006 on Guidelines for Technical Requirements for Building Structure.

ix. Minister of Health Decree No. 1405/Menkes/SK/XI/2002

x. Law No. 18 of 2008

Accordingly, the Greenship consists of six main criteria: (i) Appropriate Site Development (ASD); (ii) Energy Efficiency and Conservation (EEC); (iii) Water Conservation (WC); (iv) Material Resources and Cycles (MRC); (v) Indoor Health and Comfort (IHC); (vi) Building Environment Management (BEM) along with the sub-criteria [15]. 


\section{Methodology}

The research subjectswerethe environmentally friendly home occupants (and/or users) from several housing zones in Malang and Surabaya, East Java, Indonesia. This domain (environmentally friendly home) was selected based on its potential role in energy efficiency practices; it is estimated that the occupants significantly practice energy efficiency.

This research employs post-positivism paradigm as it determines the effects or outcomes needed to be identified. This paradigm also intends to make the ideas into small and discrete sets of tests, for example, variables consisting of hypotheses and research questions. Therefore, the most important point of post-positivism starts with a theory that needs to be tested or verified and refined to understand the world [16]. Furthermore, the quantitative research approach used in this study has been proven empirically by many researchers in studies of green consumer behavior [14-18]. In general, this research is designed to discover the users or occupants' perception of environmentally friendly homes on energy efficiency.

The data were collected using a survey method which was self-administered and crosssectionally conducted through questionnaire distribution. The advantage of this method is that it can provide a higher response rate than questionnaires distributed by mail, telephone, and electronics [17-19]. The second advantage is that respondents can be directly asked about things that are still not clear after the researchers read their responses. The third advantage is that this technique is very flexible for obtaining data. In regard to data sampling, more than 200 respondents were involved in this research.

Data analysis is highly essential in a study as it will provide answers to research problems and objectives. This research employs a descriptive analysis method. The research instruments based on the Greenship criteria related to energy efficiency, water conservation, and indoor comfort are presented in Table 1. The data measurements used a Likert scale. The guidelines for all variables measurement indicate the usage of a five point Likert scale allowing the respondents to select their level of importance with a statement. The categories available for each answer are as follows: very important (5-point score); important (4-point score); moderately important (3-point score); less important (2-point score); un-important (1-point score).

Table 1. List of greenship criteria for green home [15].

\begin{tabular}{|c|c|c|}
\hline Code & Objective & Criteria \\
\hline \multicolumn{3}{|c|}{ ENERGY EFFICIENCY \& CONSERVATION (EEC) } \\
\hline \multirow{3}{*}{ EEC 1} & \multirow{3}{*}{ Electric Sub-metering } & Providing sub-metering for lamps \\
\hline & & $\begin{array}{lll}\begin{array}{l}\text { Providing } \\
\text { airconditioner(s) }\end{array} & \text { sub-metering } & \text { for } \\
\end{array}$ \\
\hline & & Providing sub-metering for electric sockets \\
\hline \multirow[b]{2}{*}{ EEC 2} & \multirow[b]{2}{*}{ Artificial Lighting } & $\begin{array}{l}\text { Knowing the average usage of lamps } \\
\text { calculated by } \mathrm{W} \mathrm{m}^{-2}\end{array}$ \\
\hline & & $\begin{array}{l}\text { Using automatic features such as motion } \\
\text { sensor, timer, and light sensor in at least } \\
\text { one room }\end{array}$ \\
\hline \multirow{2}{*}{ EEC 3} & \multirow{2}{*}{ Air Conditioning } & $\begin{array}{l}\text { Using airconditioner(s)for } 50 \% \text { of the total } \\
\text { area at most }\end{array}$ \\
\hline & & $\begin{array}{l}\text { Understanding the COP (coefficient of } \\
\text { performance) of the airconditioner(s) }\end{array}$ \\
\hline EEC 4 & Thermal Reduction & $\begin{array}{l}\text { Using thermal absorbing material for the } \\
\text { roof }\end{array}$ \\
\hline
\end{tabular}

Table 1. continue to the next page 
Table 1. (Continued).

\begin{tabular}{|c|c|c|}
\hline Code & Objective & Criteria \\
\hline & & $\begin{array}{l}\text { Using thermal absorbing material for } \\
\text { glasses and skylights }\end{array}$ \\
\hline \multirow{2}{*}{ EEC 5} & \multirow{2}{*}{$\begin{array}{l}\text { Renewable Energy } \\
\text { Sources }\end{array}$} & $\begin{array}{l}\text { Using a solar water heater that does not } \\
\text { consume electrical energy }\end{array}$ \\
\hline & & Providing an alternative power plant \\
\hline \multicolumn{3}{|c|}{ WATER CONSERVATION } \\
\hline WAC 1 & Water-saving fitting & Using fitting for water-saving \\
\hline \multirow{3}{*}{ WAC 2} & \multirow{3}{*}{ Rainfall Utilization } & $\begin{array}{l}\text { Providing rainwater tanks with a minimum } \\
\text { capacity of } 200 \mathrm{~L}\end{array}$ \\
\hline & & $\begin{array}{l}\text { Providing rainwater tanks with a minimum } \\
\text { capacity of } 500 \mathrm{~L}\end{array}$ \\
\hline & & $\begin{array}{l}\text { Providing } 1 \mathrm{~A} \text { and using it for flushing the } \\
\text { toilet }\end{array}$ \\
\hline \multirow{2}{*}{ WAC 3} & \multirow{2}{*}{ Water-saving irrigation } & $\begin{array}{l}\text { Not using main water sources to water the } \\
\text { plants }\end{array}$ \\
\hline & & $\begin{array}{l}\text { Having a strategy of water-saving to water } \\
\text { the plants }\end{array}$ \\
\hline \multicolumn{3}{|c|}{ INDOOR HEALTH AND COMFORT (IHC) } \\
\hline \multirow{8}{*}{ IHC 1} & \multirow{8}{*}{ Indoor air Circulation } & Providing naturalventilation \\
\hline & & $\begin{array}{l}\text { Providing circulation for a minimum } 5 \% \text { to } \\
10 \% \text { of the total area }\end{array}$ \\
\hline & & $\begin{array}{l}\begin{array}{l}\text { Covering } 50 \% \text { total area with cross } \\
\text { ventilation }\end{array} \\
\end{array}$ \\
\hline & & $\begin{array}{l}\begin{array}{l}\text { Covering } 75 \% \\
\text { ventilation }\end{array} \\
\end{array}$ \\
\hline & & $\begin{array}{l}\text { Covering } 100 \% \text { total area with cross } \\
\text { ventilation }\end{array}$ \\
\hline & & Providing unnatural ventilation \\
\hline & & Putting on the exhaust fan in bathrooms \\
\hline & & Putting on the exhaust fan in the kitchen \\
\hline \multirow{2}{*}{ IHC 2} & \multirow{2}{*}{$\begin{array}{l}\text { Minimization of Polutant } \\
\text { Sources }\end{array}$} & $\begin{array}{l}\text { Using low VOC } \\
\text { compounds) wall-paint }\end{array}$ \\
\hline & & Using low VOC sealant and adhesive \\
\hline \multirow{2}{*}{ IHC 3} & \multirow{2}{*}{$\begin{array}{l}\text { Maximize Natural } \\
\text { Lighting }\end{array}$} & $\begin{array}{l}\text { Making sure that the sunlight can illuminate } \\
\text { a family room area as much as } 200 \text { lux in } \\
50 \% \text { of the room }\end{array}$ \\
\hline & & $\begin{array}{l}\text { Making sure that sunlight can illuminate a } \\
\text { bedroom area as much as } 200 \text { lux in } 50 \% \\
\text { of the room }\end{array}$ \\
\hline
\end{tabular}

\section{Results and discussion}

Tests were conducted to verify the reliability and validity of the instruments. Total of 250 questionnaires were distributed, and 200 responses were obtained; not withstanding, the number of respondents meets the minimum requirement. Statistical measurement was conducted to test the reliability and validity of the instrument. Pearson correlation and Cronbach's alpha coefficient were applied and are presented in Table 2. This approach was employed to ensure that the measurement instrument worked well. For all items, the Cronbach's alpha coefficient values were greater than the acceptable value of 0.6 , indicating that the items assigned to the constructs were reliable. 
Table 2. Validity, Reliability, and Mean

\begin{tabular}{|c|c|c|c|c|c|c|}
\hline \multirow[t]{2}{*}{ Variable } & \multirow[t]{2}{*}{ Item } & \multicolumn{2}{|c|}{$\begin{array}{c}\text { Pearson } \\
\text { Correlation } \\
\end{array}$} & \multirow{2}{*}{$\begin{array}{c}\text { Reliability } \\
\text { Cronbach } \\
\text { Alpha } \\
\end{array}$} & \multirow[t]{2}{*}{ Mean } & \multirow{2}{*}{$\begin{array}{c}\text { Av. } \\
\text { Mean }\end{array}$} \\
\hline & & $\mathbf{r}$ & Status & & & \\
\hline \multirow{11}{*}{$\begin{array}{l}\text { Energy } \\
\text { Efficiency and } \\
\text { Conservation } \\
\text { (EEC) }\end{array}$} & EEC1 & $0.530 * *$ & Valid & \multirow{11}{*}{0.886} & 3.73 & \multirow{11}{*}{3.80} \\
\hline & EEC2 & $0.771 * *$ & Valid & & 3.67 & \\
\hline & EEC3 & $0.664 * *$ & Valid & & 3.74 & \\
\hline & EEC4 & $0.758 * *$ & Valid & & 3.74 & \\
\hline & EEC5 & $0.680 * *$ & Valid & & 3.78 & \\
\hline & EEC6 & $0.676 * *$ & Valid & & 3.79 & \\
\hline & EEC7 & $0.737 * *$ & Valid & & 3.55 & \\
\hline & EEC8 & $0.700 * *$ & Valid & & 3.86 & \\
\hline & EEC9 & $0.637 * *$ & Valid & & 3.95 & \\
\hline & EEC10 & $0.707 * *$ & Valid & & 3.99 & \\
\hline & EEC11 & $0.682 * *$ & Valid & & 4.00 & \\
\hline \multirow{5}{*}{$\begin{array}{l}\text { Water } \\
\text { Conservation } \\
\text { (WC) }\end{array}$} & WC1 & $0.848 * *$ & Valid & \multirow{5}{*}{0.900} & 4.11 & \multirow{5}{*}{4.00} \\
\hline & WC2 & $0.848 * *$ & Valid & & 3.92 & \\
\hline & WC3 & $0.871 * *$ & Valid & & 3.94 & \\
\hline & WC4 & $0.848 * *$ & Valid & & 4.01 & \\
\hline & WC5 & $0.818 * *$ & Valid & & 4.04 & \\
\hline \multirow{6}{*}{$\begin{array}{l}\text { Indoor Health } \\
\text { and Comfort } \\
\text { (IHC) }\end{array}$} & IHC1 & $0.696 * *$ & Valid & \multirow{6}{*}{0.846} & 3.97 & \multirow{6}{*}{3.89} \\
\hline & IHC 2 & $0.759 * *$ & Valid & & 3.92 & \\
\hline & IHC 3 & $0.714 * *$ & Valid & & 3.84 & \\
\hline & IHC 4 & $0.807 * *$ & Valid & & 3.72 & \\
\hline & IHC 5 & $0.779 * *$ & Valid & & 3.96 & \\
\hline & IHC 6 & $0.766 * *$ & Valid & & 3.92 & \\
\hline
\end{tabular}

Based on the data shown in Table 2, EEC 11 indicated the highest mean value; the criteria address renewable energy sources with the sub-criteria of alternative power supply plant. The Water Conservation (WC) criteria indicate that WC 1 has the highest mean value, asserting that using fitting for water-saving is highly important. As for the Indoor Health and Comfort (IHC) criteria, the highest mean value at IHC1 is the Indoor Air circulation sub-criteria; it shows that it is important to have natural ventilation in an environmentally friendly home. The highest mean value of all sub-criteria in environmentally friendly homes is in the water conservation criteria.

In sequence, the users' perception of environmentally friendly homes' energy efficiency is the importance of water conservation, indoor health and comfort, and energy efficiency conservation. In Indonesia, the importance of saving water in homes has become a national issue and jargon in saving energy and electricity. Nevertheless, according to the results of the analysis, the health and comfort of the residents are also essential in the sake of energy efficiency. By providing a lot of windows or ventilation, it can naturally reduce the use of air ventilators (exhaust fan), and thus reduce the use of electrical energy as well.

\section{Conclusion}

The main objective of this paper is to study the users' perception of energy efficiency in eco-friendly homes. This study discovered that items adopted to measure all energy efficiency criteria from the Greenship provided a good reliability value; the mean values 
indicate that all criteria are essential. These findings clarified that users' perception of ecofriendly home increases along with energy consumption efficiency. The findings support recommendations on the need to consider users' factors in measuring energy efficiency in the building. This study also revealed that users already perceive that energy efficiency is highly important. Therefore, the simultaneous application of the Greenship criteria for housing is needed to achieve sustainable development goals in Indonesia.

\section{References}

1. P. Tharakan P. Summary of Indonesia's energy sector assessment. Philipines: Asian Development Bank (2015). p. 40. https://www.adb.org/sites/default/files/publication/178039/ino-paper-09-2015.pdf

2. M. Wijayaningtyas, I. Sipan, K. Lukiyanto. Informal worker phenomenon in housing construction project informal worker phenomenon in housing construction project. Paper Presented in The 3rd International Conference Construction and Building Engineering (ICONBUILD) (Palembang, Indonesia, 2017). AIP Conf. Proc. 1903:17(2017). https://aip.scitation.org/doi/abs/10.1063/1.5011575

3. N.S.A. Adiwoso, Prasetyoadi, S. Perdana. Towards indonesia sustainable future through sustainable building and construction. [Online] from http://www.mgbc.org.my/Resources/Day\%202/GBC\%20Indonesia\%20Presentations/ Country\%20Paper\%20-\%20GBC\%20Indonesia\%20Presentation\%20Paper.pdf (2013). [Accessed on July 29, 2020]

4. E.M. Elias, A.A. Bakar, A.Y. Bahaudin. Green residential buildings: The perspective of potential buyers. Paper Presented in 3rd Glob Accounting, Finance and Economic Conference (Rydges, Australia, 2013). http://repo.uum.edu.my/9451/

5. T.T. Hong. Predicting homebuyers' intentions of inhabiting eco-friendly homes: The case of a developing country. International Real Estate Symposium (IRERS) (Kuala Lumpur, Malaysia, 2012). https://core.ac.uk/download/pdf/148366427.pdf

6. M. Wijayaningtyas, T.H. Nainggolan. International journal of scientific and technology research, 9,2:2054-2059(2020). http://www.ijstr.org/finalprint/feb2020/The-Millennial-Generation-Purchase-Intention-Toward-Green-

Residential-Building.pdf

7. Dewan Energi Nasional. Outlook energi Indonesia 2016. [Indonesia's energy outlook 2016]. Jakarta: Sekretariat Jenderal Dewan Energi Nasional (2016). [in Bahasah Indonesia].

https://www.esdm.go.id/assets/media/content/outlook_energi_indonesia_2016_opt.pd $\underline{\mathrm{f}}$

8. M. Wijayaningtyas, F. Handoko, S. Hidayat. J. Phys.: Conf. Ser. 1375:1-7(2019). https://iopscience.iop.org/article/10.1088/1742-6596/1375/1/012060/meta

9. C. Wilson, H. Dowlatabadi. Annu. Rev. Environ. Resour., 32,1):169-203(2007). https://www.researchgate.net/publication/228255686_Models_of_Decision_Making_ and_Residential_Energy_Use

10. F. Handoko, E. Nursanti, M.E. Tjahjadi, J. Hutabarat, L. Mulyadi, Kustamar. Matec Web of Conferences, 164,01010:1-7(2018).

https://www.matecconferences.org/articles/matecconf/abs/2018/23/matecconf_icesti2018 01010/matecc onf_icesti2018 01010.html

11. J.H. Hwang, S.H. Yoo. Qual Quant, 48,1:63-73(2014). https://pageone.springer.com/pdf/preview/10.1007/s11135-012-9749-5

12. A. Steinemann, P. Wargocki, B. Rismanchi. Build. Environ., 112:351-358(2017). https://www.sciencedirect.com/science/article/pii/S0360132316304346?via\%3Dihub 
13. V. Fabi, G. Spigliantini, S.P. Corgnati. Energy Procedia, 111:759-769(2017). https://www.sciencedirect.com/science/article/pii/S1876610217302680

14. N. Soares, L.D. Pereira, J-.P. Ferreira, P. Conceicao, P.P. da Silva. Int. J. Sustain. High. Educ. 16,5:1-29(2015). https://www.emerald.com/insight/content/doi/10.1108/IJSHE-11-2013-0147/full/html

15. Green Building Council Indonesia. Greenship homes version 1.0. [Online] from www.greenship.org (2014). [Accessed on July 29, 2020]. [in Bahasa Indonesia].

16. J.W. Creswell, V.L.P. Clark. Designing and conducting mixed methods research. Thousand Oaks, California: Sage Publication, Inc. (2017). p. 457. https://us.sagepub.com/en-us/nam/designing-and-conducting-mixed-methodsresearch/book241842

17. N. Zainordin, S.M. Abdullah, Z.A. Baharum. AJEBS, 3,9:91-105(2012). https://fspu.uitm.edu.my/cebs/images/stories/cebs/ajebsv3n9c7p91to105.pdf

18. C. Eves, S. Kippes. Property Management, 28,3:193-208(2010). https://www.emerald.com/insight/content/doi/10.1108/02637471011051327/full/html

19. N.K. Malhotra, J.D. McCort. International Marketing Review, 18,3:235-269(2001). https://www.emerald.com/insight/content/doi/10.1108/02651330110396505/full/html 